\title{
REGIONAL SCIENCE AND PUBLIC MANAGEMENT
}

\author{
Joseph V. Cartwright"
}

When I was a sophomore in college, I shared a suite of rooms with a fun-loving and hard-studying group of individuals, very much like the members of the Southern Regional Science Association. All of my college friends prided themselves on their individuality, again very much like the members of the SRSA. In fact, "being into your own thing" was how we formed our college group. Peer pressure worked to coerce each of us to value uniqueness; our commonality was that each of us was different, or so I like to reminisce. Naturally, most of us had different majors. Our sensitive egos, high in need for achievement and attention, did not want to stifle each other by crowding onto the common turf of the same books and professors, and then merely compete for the top grades.

One of the distinctive customs of our group, in its own way very much like the annual meetings of the SRSA, was a late night walk around the campus and environs. Covering several miles in about an hour, we would attempt to explain to each other what we had learned from our individual studies that night. We, somewhat unconsciously, were carrying on the ancient Greek tradition of peripatetic philosophy - conducting discourse while pacing on a journey. So I invite you to take a metaphorical walk as I explain what I've learned over the past years as a regional scientist and public manager.

As a preamble, a description of my job may provide us a common perspective. After working for almost ten years as a regional model-builder at the Bureau of Economic Analysis, I've been a senior project manager with the Office of Economic Adjustment in the Department of Defense for the past five years. My work is focused on the analysis and management of the off-base economic and fiscal impacts of opening and closing military bases. My job is to set up organizations that analyze current situations and take action to achieve new outcomes. I travel extensively, averaging 25 trips a year to work with local and state governments affected by military bases. I remember looking at an itinerary that included a trip from Jacksonville, Florida to Fairbanks, Alaska; on extreme days that

"Office of Economic Adjustment, U.S. Department of Defense. Presidential address presented at the annual meeting of the Southern Regional Science Association, Chapel Hill, N.C., April $28,1989$. can be a 150 degree temperature differential. But I'm not going to spend my alloted time talking about the weather in different places. Rather I'd like to discuss the relationship between regional science and public management.

What is regional science? Is it the study of the various regions of a nation? Is it the study of the relationships among sub-national entities? Does it encompass economics, geography, demography, and many other fields, when those fields graft the adjective "regional" onto themselves? My answer to all of these questions is yes. Is regional science truly a science? If descriptive taxonomy, accompanied by hypothesis testing, is the hallmark of science, then I can accept the assertion that regional science is a valid term.

What is public management? First, what is management? According to the dictionary, to manage means to bring about, to have charge of. The word "manage" makes us think of directing a series of events toward an outcome, often undefined at the start. Synonyms for manage, on a scale from passive to active, include: arrange, conduct, guide, regulate, engineer, contrive, maybe even manipulate. Beware of managers who are manipulators, they care more about themselves than about preference revelation, Lindahl equilibrium, or Pareto optimality!

Good management is based on individual technical competence and teamwork. The latter includes communication, delegation, and responsibility. Like civil engineers, not an unruly group, managers use planning charts to identify critical paths. Good managers know that management by objectives is more than the title of a book. Good managers have the ability to make decisions and achieve results. Good managers are ethical, which, at a "golden-rule" minimun, means seeking an outcome as though you were on the other side. Beware of managers who say "the other side" too often; they're usually thinking too much about their side!

What is public management? The differences between public and private management have to do with the complexity, diversity, duration, and openness of the issues that require public management. For example, in land use planning and economic development, the following table shows a list of players, humorous strategies, and goals:

In public management, everybody gets to play and furthermore they do it in the open. For this five-player 
Table 1

Strategies and Goals of Participants in Planning for Economic Development

\begin{tabular}{lll}
\hline \hline Player & Strategy & \multicolumn{1}{c}{ Goal } \\
\hline Planner & Build consensus & Orderly development \\
Consultant & Study/restudy & Complete contract \\
Developer & Minimize interference & Maximize profits \\
Citizen & Personal advocacy & Self protection \\
Politician & Avoid stand & Re-election \\
\hline \hline
\end{tabular}

game, the escalating styles of play are: communication, facilitation, negotiation, mediation, arbitration, litigation, and legislation.

To recapitulate, I have defined regional science as a type of analysis that is based on experience and aims towards constructs that describe reality. On the other hand, management is the attempt to create new outcomes, that is, future realities. Policy, which is defined as a definite course of action selected, is the intervening variable, in my work, between regional science and public management.

Policy can be viewed as the output of analysis and a major input to management. Policy is the intermediate present that links the past with the future. In my work, regional science, i.e. regional economic and fiscal analysis of the impacts of military bases, often becomes the basis for a policy recommendation: for example, build a new elementary school with specific cost shares among local, state, and federal governments. The management aspect can be viewed in a narrow legislative sense as securing the authorizing and appropriating laws to fund the recommended cost-sharing policy.

I think it is important to recognize the analysispolicy-management continuum and where we stand on it at a given moment. In the real world, it is unfortunate that analysts and managers often adopt hands-off attitudes toward one another. At times, that can be fine. After all, there are gains to be had from specialization; but those gains are fully realized only through trade, that is, through communication, negotiation, and eventual exchange. Selfprotecting barriers to trade among analysts and managers reduce public welfare.

While it would take a much longer paper to describe fully the roles, responsibilities, and interrelations of analysts, policy-makers, and hands-on managers, let me encourage you to draw your own conclusions from reading the four policy and management references listed at the end of this paper. One conclusion is that analysts exert less influence than they might because they do not make sufficient effort to learn how issues look from a manager's point of view. For analysts who aspire to advise policy makers and influence managers, the cited authors provide much that should be taken seriously. My favorite, lighthearted suggestions are:

(1) it's okay to think like an economist, just don't write like one; write like a journalist: emphasize a few simple numbers and learn the history of an issue;

(2) think like a manager about administration and implementation: who is going to do what needs to be done and how are they going to do it.

In a managerial context, regional scientists with backgrounds in economics or geography have much to learn from the practical work of regional planners and the extension work of agricultural economists. In defense of regional scientists everywhere, I can say that training in regional science is good preparation for learning to live with the complexity and diversity that are the constant themes of public management. I've met many managers who don't have a sense of place - the simplest of all regional science concepts. A sense of place should create the expectation that the specific managerial process that worked in one place will have to be transformed to work in another.

While training in regional science may help public managers, I can recommend, on the other hand, that regional scientists acquire a realistic, if only vicarious, understanding of public management. This understanding might be enhanced by courses such as one at the University of Maryland in the public management program entitled: Management Strategies in Public Organizations. The course description reads, in part:

Problem areas studied include setting out an organization's goals, obtaining as well as protecting a mandate for a new program, designing a service delivery system, implementing a new pro- 
gram, supervising subordinates, marketing a new program to the public, and facing ethical dilemmas.

Since much of what we discuss at these annual meetings concerns the implications of regional science for describing and changing the world, let me leave for your consideraton a two-fold idea. First, regional policy must be well crafted by the tools of regional science research; second, policy is only one of many management tools that must be used to achieve new outcomes. Good science, plus good policy, plus poor management can equate to poor outcomes.

\section{References}

Leman, Christopher K. and Robert H. Nelson. "Ten Commandments for Policy Economists." Journal of Policy Analysis and Management. 1:1 (1981). 97-117

Nelson, Robert H. "The Economics Profession and the Making of Public Policy." Journal of Economic Literature. 25 (1987). 49-91.

Neustadt, Richard E. and Emest R. May. Thinking in Time: The Uses of History for Decision Makers. The Free Press, 1986.

Verdier, James M. "Advising Congressional Decision Makers: Guidelines for Economists." Journal of Policy Analysis and Management. 3:3 (1984). 421-438. 